\section{B A Institute of \\ YK Business Administration \\ 六下 \\ Karachi \\ Leadership and Ideas for Tomorrow}

Business Review

Volume 8 Issue 2 July-December 2013

$7-1-2013$

\title{
Factors leading to decentralization of ICT companies: The case of Multimedia Super Corridor, Malaysia
}

\author{
Muhammad Asim Tufail \\ Northern Alberta Institute of Technology, Alberta, Canada \\ Abu Hassan Abu Bakar \\ Northern Alberta Institute of Technology, Alberta, Canada \\ Wiwied Virgiyanti \\ Northern Alberta Institute of Technology, Alberta, Canada \\ Faisal Manzoor Arain \\ Northern Alberta Institute of Technology, Alberta, Canada
}

Follow this and additional works at: https://ir.iba.edu.pk/businessreview

Part of the Communication Technology and New Media Commons, and the Digital Communications and Networking Commons

\section{(c) (;)}

This work is licensed under a Creative Commons Attribution 4.0 International License.

\section{Recommended Citation}

Tufail, M. A., Abu Bakar, A., Virgiyanti, W., \& Arain, F. (2013). Factors leading to decentralization of ICT companies: The case of Multimedia Super Corridor, Malaysia. Business Review, 8(2), 83-97. Retrieved from https://doi.org/10.54784/1990-6587.1288

This article is brought to you by iRepository for open access under the Creative Commons Attribution 4.0 License and is available at https://ir.iba.edu.pk/businessreview/vol8/iss2/7. For more information, please contact irepository@iba.edu.pk. 


\title{
ARTICLE
}

\section{FACTORS LEADING TO DECENTRALIZATION OF ICT COMPANIES: The case of multimedia super corridor, Malaysia}

\author{
Muhammad Asim Tufail \\ Abu Hassan Abu Bakar \\ Wiwied Virgiyanti \\ Faisal Manzoor Arain \\ Northern Alberta Institute of Technology, Alberta, Canada
}

\begin{abstract}
Technological development in the information and communication technologies (ICT) sector is essential to attain sustainability in today's era. Cities have developed satellite towns at the periphery with hi-fidelity digital and physical infrastructure which converts a single cantered city into a multi cantered one. In case of Kuala Lumpur Metropolitan Area (KLMA) the shift of civic services to Putrajaya and development of Multimedia Super Corridor (MSC) which offers incentives to local and foreign companies to develop a super block of research and development based economic sector. This development spearheaded the Malaysian Vision 2020 of knowledge based economy and society and has become an attraction to the business community across Malaysia. The purpose of this paper is to discuss the key factors that have attracted the companies to physically move from KLMA to MSC. To achieve the study objectives, a questionnaire survey and interviews were carried out to collect pertinent information from companies focusing on businesses in finance, insurance and real-estate. The data collected was analyzed to identify the ranking of variables of Bill of Guarantees offered in MSC policy. The study findings suggest that in addition to good infrastructure and good working environment, the tax exemption offered by the government has been the driving force for companies to decentralize towards MSC. The results suggest that the better infrastructure, connectivity, low taxes, low telecommunication tariffs, and land cost were considered as the most important factors for decentralization of ICT companies in Malaysia. The other factors that were highlighted in this study include low cost of doing business, and competitive conditions for attracting companies to avail MSC status. The study also presents the initial hindrances faced by the ICT companies i.e., accessibility issue for city clients and workers, high rental rates of the property and slow development of supportive public amenities in MSC.
\end{abstract}

Keywords: ICT; Knowledge based economy; multimedia, super-corridor, decentralization

\section{Introduction}

The high living standards of Malaysia have generated many manufacturing and business employment opportunities in global business industry. The growth of towns has accelerated as a result of high population growth. The importance of effective ICT to address demands of the 
business community has increased many folds. Information technology has become strongly established as a supporting tool for many professional tasks in recent years.

Over the last two decades, the importance of the ICT in business practices has increased significantly. The world is indeed becoming a smaller place; more and more companies are operating across geographic and cultural boundaries. New communication and distribution technologies, and the removal of trade and investment barriers, have created truly global markets with global competition for goods, services and capital, and even corporate control.

Several studies have suggested that the office location research could be categorized into two main groups. Firstly, it covers the central location tendency of offices, and secondly, it deals with the likely effects of telecommunications technology on the spatial pattern and distribution of offices (Kutay, 1986). The result of globalization exposing regional markets to a wider spectrum of competition as well as providing possibilities for urban centres to shift from the more restrictive central place orientation of economic interaction to one based on international networks (Goddard, 1990).

In such context, city administrators, educational institutions, e-entrepreneurs, the information technology (IT) industry, community developers, planners, and urban designers, among others, have come together to reinvent locales as more liveable, sustainable and vibrant, world-class, digitally connected communities. The rallying cry of these coalitions is often because of urban sprawl and its consequences, including central city decline; lack of affordable housing; long commutes; traffic gridlock; fast-disappearing open space; environmental pollution; and automobile-dependent, mass-produced, boring development patterns (Katz, 2002; Henton and Walesh, 1998).

Therefore, the questions of the office locations effected by ICT are appropriate conventional and thus, this paper explores the factors effecting the movement of information and communication technology (ICT) companies towards the Multimedia Super Corridor (MSC), Malaysia, hypothesizing that "Due to advanced ICT infrastructure and incentives provided by the MSC, global as well as local business companies are moving from the city centre towards the MSC in order to get maximum output of the advanced infrastructure and greater incentives offered by the MSC development policies".

It also focuses on, how the development of infrastructure, in addition to comprehensive policies has attracted the companies to physically move towards the MSC thus, forming cluster of information and multimedia intensive companies in a designated area. The study objectives include Identification of the effects of technology on decentralization of ICT companies, the driver for the decentralization, the factors of decentralization of ICT companies from the CBD of Kuala Lumpur to MSC area, analysis and assessment of the effectiveness of existing Bill of Guarantees offered by MSC and finally the recommendations for future policy direction.

\section{Factors Influencing the Choice of Office Location}

One of the significant factors in locating office facilities in the periphery of a city or in suburban locations is the occupancy cost. In addition to space adaptability, operating expenses that are absorbed by the tenant are closely associated with such costs (Moss, 1999). In addition, the basic cost of labor can be reduced with intensifying usage of ICT, given that the sophisticated technology is in a position to improve the quality and efficiency of labor, and enable speedy and cheaper flows of information for both firms and individuals to operate from any location 
(Prud'homme, 1992; Stutz and de Souza, 1998). Although the increased availability of telecommunication technology and the reduction in its expense has been important, the driving force toward the globalization of back office services are demographics, rental cost and labor costs (Dickstein, 1999).

Moreover, entry-level wages in the computer field are rising faster than inflation in the developed world with high job turnover (Goff, 1990). In case of software development companies, recognizing the shortage of programmers and fearing an escalation of labor costs as companies compete for qualified programmers; many companies have started to locate their software development and maintenance facilities in Ireland and in developing countries as India to take advantage of the lower wages (Ludlum, 1987; Tagare, 1989; Goff, 1990; Brandt, 1991).

Studies by Stutz and de Souza (1998) and Sassen (2000) also show that use of ICT has been seen by multinational corporations (MNCs) as the most important element to increase their competitive advantage and to support a business unit's competitive strategy, and therefore performance and productivity. ICT allows an efficient decentralization of corporate activities by providing speedy communication lines and streamlining product designs, processing and analyzing of business information about innovations, markets, competitors and environmental changes, hence sharpening the competitive edge of MNCs in the market place.

Furthermore, Local or regional disconnection has emerged alongside an uneven global interconnection in the production of urban space (Wong, 2003). The reliability of connectivity with the global telecommunication network and the band-width remain an important factor for the information incentive firms using high level of ICT's. Mitchell (1995) puts this notion as; "low baud-rate connection puts you out in the boonies, where the flow of information reduces to a trickle, where you cannot make so many connections, and where interactions are less intense.... Since the cost of high bandwidth cable connection grows with distance, information hotspots often develop around high-capacity data sources. Much as oases grow up around well”.

The comparative advantages of dense urban areas are not limited to high-bandwidth access. They extend to the deployment of new information technologies in general, since most cities that have a high concentration of information industries such as finance, insurance, and real estate are also high-use telecommunications customers (Guldman, 1994).

Much more than low cost the main advantage of shifting business operations to low-cost countries comes from a combination of lower wages and the improvement in the quality and price of international telecommunications. A report by HSBC says that the cost of a one-minute telephone call from India to America and Britain has fallen by more than 80 percent (Jebson, 2003).

State and local taxes can also influence the cost of a particular location; however, numerous studies have pointed to the limited role of state and local tax rates in determining corporate location (Netzer, 1985) but in the near past it has been seen that countries seeking business being off-shored are offering exemption of income tax to get more benefits of the capital investment and thus getting advantages in the job opportunities and development of overall economy on a city and regional basis (Campos, et al 2003).

ICT technologies are destined to change the spatial urban scene. As the technologies will develop and become more sophisticated, the cities having the infrastructure that can meet the requirements of the information age will be the nucleus of the economic activities controlling the 
diverse operations anywhere in the world. In fact, because telecommunications have also facilitated the extension of market reach and thus, the rise of the multinational firm, cities with access to the most sophisticated telecommunication systems have a comparative advantage with regard to choice of information services. Front-office functions, reliant on direct client contact and using technology to coordinate dispersed operations, are likely to become highly centralized in a small number of information-based cities (Moss, 1999).

Strong communications linkages help develop an overall culture of entrepreneurship, whether this is applied to social or economic ends. A vibrancy fostered by a local talent pool generates learning processes embedded within a community, and channels of external communication built to reach selected outsiders speed up knowledge and technology transfer. General transitions in the history of societies, cities and their economies are reflected in how cities develop and how urban planning is conceived. The form and the priorities of a city-making to develop a city's assets are different under the era of labour-intensive mass production-based industrialization from those of high-technology-focused and knowledge-based development (Landry, 2008).

The comparative advantage of large metropolitan regions as the sites for new capital investment in telecommunications should allow information-intensive cities to maintain their economic strength as places where both face-to-face and electronic communications are affordable and accessible. Far from proving the unmitigated decentralizing force of technology, current events bear out Thomas Mandeville (1983) concluded that technology facilitated both centralization and decentralization of tasks and jobs. The development of Internet-related technologies was also having a profound effect on the headquarters of major financial firms by allowing a corporation's headquarters office to exert a new form of control over their satellite offices (Stirland, 1997).

In this context, Ronald Abler predicted that advances in information transmission may soon permit us to disperse information gathering and decision-making activities away from metropolitan centers and electronic communications media will make all kinds of information equally abundant everywhere (Abler, 1970). Mulgan (1991) added further that cities were to be redefined as a system for producing and switching information.

As the size and importance of a city is determined by the amounts and kinds of information flowing into and out of it, and by the way it is interconnected with other cities in the national information flow network (Abler, 1970). It is now widely argued that the increasingly pervasive applications of linked computer, media and telecommunications technologies constitute nothing less than a wholesale shift of our economy, society and culture. Social scientists regularly now talk of a new, emerging 'digital age', and 'information society,' or a 'network society' (Gosling, 1997; Castells, 1996). Such a transition is widely believed to be a new industrial revolution, a societal technological and economic shift across capitalist civilization of similar magnitude to the industrial revolution through which, every aspect of society is transformed (Graham and Marvin, 1996).

The heightened use of information technologies allows firms to centralize key executive and decision-making functions in a handful of central cities, while dispersing the routine, dataprocessing, and support activities to sites on the edge of large metropolitan regions. Telecommunication systems are not leading to the obsolescence of central cities, but are allowing the face-to-face decisions and transactions that occur in major financial capitals to serve 
geographically larger markets. The deregulation of the communication industry, combined with advances in new technology, presents a particularly important challenge for planners, developers, and managers of office space. Communication and information technologies are creating new choices in office location and new demands for office structures that can accommodate modern information systems (Moss, 1999) specially for planners it is quite evident that they have to adopt to how the new technologies are being absorbed in the current socio-economic setup of a city and how to plan according to the needs of the information age with better public policies and infrastructure in place.

The rush to build fiber optic systems by telecommunication companies in the United States resembled the rush to build railroads in the $19^{\text {th }}$ century; as if, whoever builds the first integrated network captures much of the long distance business (Johnston, 1985).

Another important social impact of using computing and telecommunications technology for distributed work involves changes in land use patterns. A commonly held hypothesis is that distributed work will make it possible for people to move even farther from central sites than they currently live, possibly leading to a net increase in travel. Again, the empirical evidence (Nilles, 1991; Mokhtarian, 1994) has not borne out the hypothesis that distributed work will lead to fewer but longer commuting trips in aggregate, although no long-term evaluation has been made. A simple theoretical model based on economic location theory (Lund and Mokhtarian, 1994) suggests that even after optimal residential relocation occurs, total commute-miles traveled will generally be lower because of more widespread telecommuting, but more research is needed to refine such a model and to test empirically.

Thus, the leading factors effecting the choice of location by information incentive companies are identified as; infrastructure, area prestige, easy access to office location, connectivity, labour and operating cost, telecom tariffs, taxes, security, land cost and competitive condition for ease of doing business.

\section{Knowledge Based Economy}

According to Drucker (1993), this is the beginning of the knowledge society in which the basic economic resource is no longer capital, or natural resources nor labour, but is and will be knowledge. The twenty-first century is a century of knowledge economy or k-economy. The $21^{\text {st }}$ Century is also being identified as the 'Century of Cities' and their economies as knowledge economies (Landry, 2000). Carrillo combined these two and identified the 21st Century as the “Century of Knowledge Cities” (Carrillo, 2006).

Malaysia started to lay the foundation for the knowledge-based economy in the mid1990s, with the launching of the National Information Technology Agenda (NITA) and the Multimedia Super Corridor (MSC). It is now more than ten years that this technology region has been launched. The MSC strives to create an ideal IT and multimedia environment as well as a global test-bed to enable Malaysia to be in the mainstream of activities necessary to attract knowledge workers, techno-entrepreneurs and high-technology industries (Malaysia, 2001).

\section{Technology and Regional Development in KIma}

The Kuala Lumpur Metropolitan Area with its importance in national socioeconomic and urban development has been historically the city to be equipped with extensive telecommunication infrastructures meant for socioeconomic and administration activities. Kuala Lumpur is the capital 
of the nation, its economic catchments encompasses the entire country. It covers a total area of approximately 4,000 square kilometres. It is estimated that the population for Kuala Lumpur in 2000 was 1.42 million people. The per capita GDP for Kuala Lumpur during the period 1995 to 2000 rose from RM22,799 to RM30,727 (Note: at the time of writing, US\$ 1 is RM 3.70 approx), an average annual growth rate of 6.1 percent which was more than twice that of the national average (Malaysia, 2003). This shows that, offices in KLMA enjoy more advance communication infrastructures and services than other major cities in this country and could have higher information and communication sophistication and utilization level, which might effect the decision to decentralize. Hence, offices in the city of Kuala Lumpur could be more adaptive towards ICT applications which might influence the office decision to locate outside city centre area.

The transformation of Kuala Lumpur and its wider urban region during the last decade demands greater critical scrutiny than it has so far attracted. Three issues in particular motivate this profile. First, theme is of Kuala Lumpur region as a "globalizing city". Since the early 1990s, Kuala Lumpur has changed from federal capital to a "node" in global networks. It is this globalizing shift which forms an important focus on its profile. The second motivation concerns the nature of the development of the city, population increase, spatial expansion and economic growth over several decades that have changed its urban landscape. The third theme in the Kuala Lumpur area is its status as an urban region forming part of a broader Klang Valley urban region, planners and policy makers are now acknowledging the existence of a more extensive Kuala Lumpur Metropolitan Area (KLMA). The centralization of political authority, particularly within Kuala Lumpur Federal Territory, has made this the focus of national development project (Bunnell, et al., 2002).

\section{The Multimedia Super Corridor (Msc)}

MSC is well positioned as a cost effective, high quality location for knowledge based 'hub' activities. It is an initiative to create an integrated environment with all unique elements and attributes needed to build a global multimedia hub. Its physical location is in a green-field corridor of $15 \mathrm{~km}$ width by $50 \mathrm{~km}$ length, stretching from the Kuala Lumpur City Centre (KLCC) to the Kuala Lumpur International Airport (KLIA). The MSC houses 5 Cyber cities namely; Cyberjaya, Technology Park Malaysia (TPM) Kuala Lumpur City Centre (KLCC), Universiti Putra Malaysia - Multimedia Technical Development Corporation and Kuala Lumpur Tower with ample space available for business setup (see Table 1). Cyberjaya is the nucleus of the MSC and is the home of the nation's high-tech ICT industry. Many large global companies have established their presence here, serving its Asia and even global business process. Attributes such as political and economic stability and pro-business Government contribute to attract even more ICT investments (MDC, 2003; MDC, 2004; MDC, 2008).

Table 1: Office Space Distribution in Cyber Cities within the MSC

\begin{tabular}{|l|l|l|}
\hline \multicolumn{1}{|c|}{ Cybercities } & Area & Current Office Space Available \\
\hline Cyberjaya & $753,496,553 \mathrm{ft}^{2}$ & $3,030,600 \mathrm{ft}^{2}$ \\
\hline Technology Park Malaysia & $9,978,590 \mathrm{ft}^{2}$ & $1,513,245 \mathrm{ft}^{2}$ \\
\hline $\begin{array}{l}\text { Universiti Putra Malaysia-Multimedia } \\
\text { Technical Development Corporation }\end{array}$ & $1,690,179 \mathrm{ft}^{2}$ & $137,874 \mathrm{ft}^{2}$ \\
\hline Kuala Lumpur City Centre & $4,104,404 \mathrm{ft}^{2}$ & $2,360,000 \mathrm{ft}^{2}$ \\
\hline
\end{tabular}

Source: MDC (2004, 2008). 
MSC status companies are largely made up of small and medium sized companies with paid-up capital of less than RM 500,000. The technological focus of these companies is in all areas of ICT ranging from software development to wireless technologies. The total number of employees to be by the end of 2012 was projected to be 75,000 people (MDC, 2008).

Many companies with national and global operations are beginning to consolidate segments of its internal operations such as IT support, human resource, financial processing and customer management from multiple locations into a single hub serving many nations. Improving global communication facilities, desire of companies to achieve operational efficiencies, effectiveness and a constant drive to save on costs, further encourages this phenomenon. A.T. Kearney's Top 10 rankings of countries for offshore location attractiveness are as follows (Kearney, 2009):

Table 2: Top 10 ranking of countries for offshore location attractiveness

\begin{tabular}{|c|c|c|c|l|c|}
\hline $\begin{array}{c}\text { Ra } \\
\text { nk }\end{array}$ & Country & $\begin{array}{c}\text { Financial } \\
\text { Attractiveness }\end{array}$ & $\begin{array}{c}\text { People Skills \& } \\
\text { Availability }\end{array}$ & $\begin{array}{l}\text { Business } \\
\text { Environment }\end{array}$ & $\begin{array}{c}\text { Total } \\
\text { Score }\end{array}$ \\
\hline 1 & India & 3.13 & 2.48 & 1.30 & 6.91 \\
\hline 2 & China & 2.59 & 2.33 & 1.37 & 6.29 \\
\hline 3 & Malaysia & 2.76 & 1.24 & 1.97 & 5.98 \\
\hline 4 & Thailand & 3.05 & 1.30 & 1.41 & 5.77 \\
\hline 5 & Indonesia & 3.23 & 1.47 & 0.99 & 5.59 \\
\hline 6 & Egypt & 3.07 & 1.20 & 1.37 & 5.64 \\
\hline 7 & Philippines & 3.19 & 1.17 & 1.24 & 5.60 \\
\hline 8 & Chile & 2.41 & 1.20 & 1.89 & 5.50 \\
\hline 9 & Jordan & 2.99 & 0.91 & 1.59 & 5.49 \\
\hline 10 & Vietnam & 3.21 & 1.02 & 1.24 & 5.47 \\
\hline
\end{tabular}

The weight distribution for the 3 categories is 40:30:30. Financial attractiveness is rated on the scale of 0-4 and the categories of people skills and availability and business environment are rated on the scale of 0-3.Source: (A.T. Kearney, 2009)

According to this report Malaysia has been ranked as the third most suitable country for outsourcing business after India and China (Kearney, 2009).Companies with a special status are entitled to enjoy the incentives and benefits backed by the Bill of Guarantees which commits the following to the companies:

a) Provide a world-class physical and information infrastructure

b) Allow unrestricted employment of local and foreign knowledge workers

c) Ensure freedom of ownership by exempting companies with MSC status from local ownership requirements

d) Give the freedom to source capital globally for MSC infrastructure and the right to borrow funds globally

e) Provide competitive financial incentives; include Pioneer Status (100\% Tax exemption) for up to ten years or an Investment Tax Allowance for up to five years, and no duties on the importation of multimedia equipment

f) Become a regional leader in intellectual property protection and cyber laws

g) Ensure no censorship of the internet 
h) Provide globally competitive telecommunication tariffs

i) Tender key MSC infrastructure contracts to leading companies willing to use the MSC as their regional hub.

j) Provide a high-powered agency to act as an effective one-stop super shop.

\section{Research Methodology}

Through the above literature review, the 10 leading factors affecting the choice of location by information incentive companies were identified. The factors included the infrastructure, area prestige, easy access to office location, connectivity, labour and operating cost, telecom tariffs, taxes, security, land cost and competitive condition for ease of doing business. The questionnaire survey was restricted to the ICT companies who were located in MSC area. The selection of firms has been limited to firms from the economic sectors, namely banking, finance and insurance sector; real estate and property; information technology (IT) and telecommunication sector, as these are the strongest growing economic sectors in the urban economy, for which the survey has been targeted at large, small and medium size private firms which have taken up the MSC status (Department of Statistics, 1998). This is due to the application of significant information and communication technologies in these companies, which contributes to the nation's ICT growth and advancement. The respondents of the survey were targeted at firm owner, director, managers or senior executives located in KLMA. For sampling design, the method of stratified random sampling was used to select samples from the population which was of a total of 71 out of which, a response of 30 (42.3\%) was gathered. Ranked data was further gathered on the response to the bill of guarantees offered in the MSC policy.

Further more, in this study, for the testing of hypothesis, the statistical technique of Mann-Whitney $U$ test has been used. It is a simple test of finding a significant difference between two sample sets of data. It tests whether the two sets of data differ from each other on ranked scores. It is a non parametric test, which means it is not restricted by any assumption about the nature of population from which the sample has been taken.

\section{Results and Discussion}

Response is gathered on the driver to move the front-office and back-office location. According to the analysis of the response; better infrastructure, connectivity and low taxes has been found to be the major attraction for companies to move their office location The overall population of 30 had a front-office set up but only 12 out of the total also had a back-office in addition to the front-office (See Table 3). 
Table 3: Driver to move office from existing location

\begin{tabular}{|l|l|l|l|l|l|l|}
\hline \multirow{2}{*}{ Driver for Shift } & \multicolumn{3}{|l|}{ Front-office } & \multicolumn{3}{l|}{ Back-office } \\
\cline { 2 - 7 } & Yes & No & Yes - (\%) & Yes & No & Yes - (\%) \\
\hline Better infrastructure & 21 & 9 & 70 & 11 & 1 & 91.6 \\
\hline Area Prestige & 10 & 20 & 33.3 & 3 & 9 & 25.0 \\
\hline Easy Access to Office & 9 & 21 & 30.3 & 5 & 7 & 41.6 \\
\hline Connectivity & 19 & 11 & 63.3 & 8 & 4 & 66.6 \\
\hline Labour Cost & 7 & 23 & 23.3 & 4 & 8 & 33.3 \\
\hline Low Telecomm. Tariffs & 13 & 17 & 43.3 & 4 & 8 & 33.3 \\
\hline Low Taxes & 18 & 12 & 60 & 7 & 5 & 58.3 \\
\hline Security & 7 & 23 & 23.3 & 2 & 10 & 16.7 \\
\hline Land Cost & 11 & 19 & 36.7 & 6 & 6 & 50 \\
\hline Competitive Conditions & 9 & 21 & 30 & 3 & 9 & 25 \\
\hline Other & 1 & 29 & 3.3 & 2 & 10 & 16.7 \\
\hline \multicolumn{7}{|l|}{} \\
\hline
\end{tabular}

\section{Better Infrastructure}

Developed infrastructure is vital in selection of front and back office premises. Built-up infrastructure with guarantee of reliable services is backbone to the ICT based businesses as they rely more on virtual connectivity than face to face meetings. Better infrastructure has been ranked at the highest of $70 \%$ for showing that, for technology based companies it remains the priority as they completely depend on technology itself to conduct their businesses.

Another response has been gathered on the same factors as drivers to shift back-office location based on the division of offices into front and back offices has concluded to the same response as shifting of office locations but infrastructure accumulating to over all $91.6 \%$ has been of the highest attraction as back offices rely on stability of services reliability for connectivity to the front offices located in different regions.

\section{Connectivity}

The second highest response has been to the connectivity which accumulates to $63 \%$ by the front office and $66.6 \%$ for the back office because the information incentive companies need to have high level of connection reliability to other locations in order to send and retrieve the latest data from and to the back-offices world wide.

\section{Taxes}

The third most important factor influencing the office location decision has been the low taxes, as MSC is mostly build up of SMEs it was evident that such companies have to cut down on their costs to remain competitive and low taxes are quite beneficiary to them in this regard, specially as BOG guarantees up to ten years of tax holidays for companies choosing MSC for their businesses.

In response to the BOG offered in MSC policy, it was visualized that in addition to tax exemption, world class infrastructure competitive telecom tariffs, unrestricted employment of foreign workers and freedom of ownership has been ranked above the mean by foreign companies, 
while MDC as one stop super shop, Infrastructure tenders to be given to MSC companies and freedom to source capital globally has been of the interest of locally owned companies (Figure. 3).

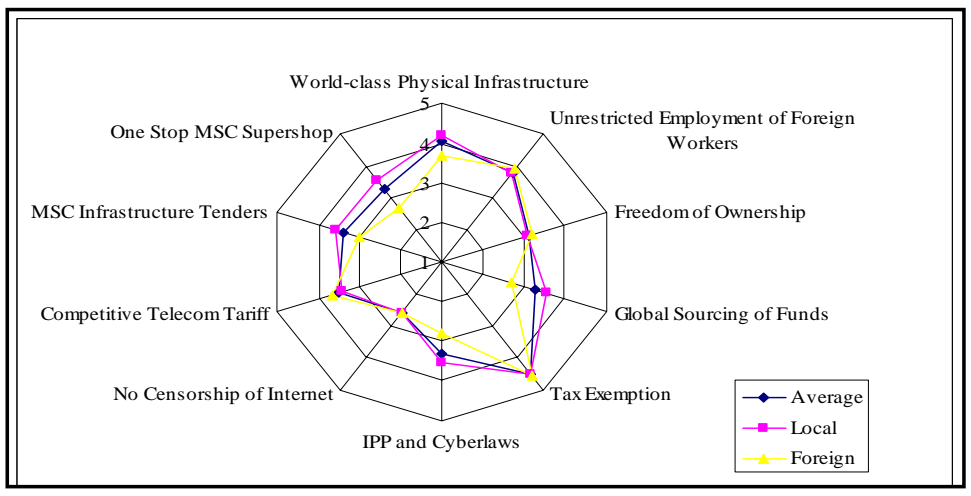

Figure 3: Response of foreign and local companies to MSC’s Bill of Guarantee

By the data gathered it was clearly seen that with the passage of time and outsourcing of business to the cheaper locations world over, the attraction to the incentives offered has differed. As companies taking up the MSC status before five years has ranked tax exemption offer in bill of guarantees as high attraction, later on, for the companies choosing to locate in the MSC area it was not that interesting, while global sourcing of funds and freedom of ownership by exempting foreign companies from local ownership requirements and freedom to source globally has become of more high a choice for the new companies as compared to older companies located in the area. It also concluded that more companies have located in the MSC within last five years then before that time (see Figure 4).

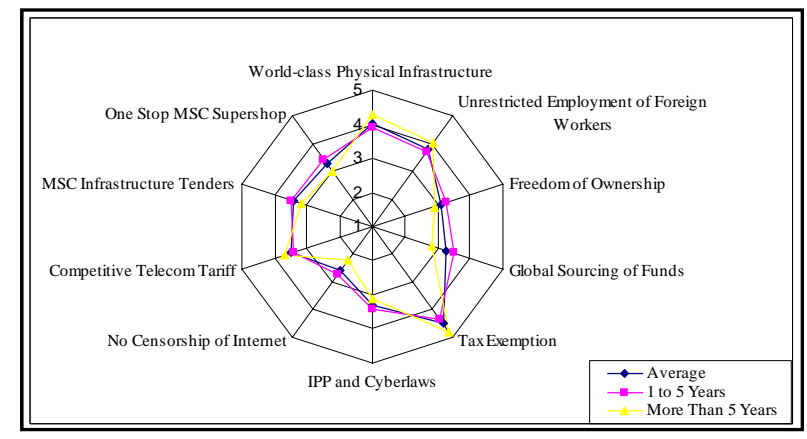

Figure 4: Response of companies to MSC's Bill of Guarantee by time of inception.

It was also observed that companies located in the MSC area highly rely on internet as the basic mode of communication, that is being Internet and Extranet as extranet depends on internet it results in $90 \%$ of the total. Only one company responded to have its own independent wide area network while two companies were reported to be using there own communication system. This shows confidence of the companies on the available connectivity present in the MSC as being 99.9\% reliable (NASSCOM, 2003) (see Table 4). 
Table 4: Mode of Communication in Offices

\begin{tabular}{|c|c|c|}
\hline Mode of Communication & Frequency & Percent \\
\hline Wide Area Network & 1 & 3.3 \\
\hline Personal Communication system & 2 & 6.7 \\
\hline Internet & 21 & 70.0 \\
\hline Extranet & 6 & 20.0 \\
\hline Total & 30 & 100.0 \\
\hline
\end{tabular}

Overall, satisfaction on tax exemption $86.7 \%$, world class infrastructure provision $66.6 \%$ and unrestricted employment of foreign workers $63.3 \%$ has proven to be the major attraction for companies choosing to locate in the MSC area. This data concludes it clearly that companies locating in the MSC are attracted to it the comprehensive Bill of Guarantees offered in its policy of development. Thus converting the area into a hub of knowledge based economic cluster.

Table 5: Ranking percentages of the most attractive incentives offered in MSC Policy

\begin{tabular}{|l|l|l|l|l|}
\hline \multicolumn{2}{|c|}{ Ranking } & \multicolumn{1}{c|}{$\begin{array}{c}\text { Tax } \\
\text { Exemption }\end{array}$} & $\begin{array}{c}\text { World Class } \\
\text { Infrastructure }\end{array}$ & \multicolumn{1}{c|}{$\begin{array}{c}\text { Employment of } \\
\text { Foreign Workers }\end{array}$} \\
\cline { 3 - 6 } & \multicolumn{1}{|c|}{ Percent } & \multicolumn{1}{c|}{ Percent } & \multicolumn{2}{c|}{ Percent } \\
\hline 1 & Highly Recommended & 66.7 & 43.3 & 33.3 \\
\hline 2 & Most Recommended & 20.0 & 23.3 & 30.0 \\
\hline 3 & Moderate Recommended & 10.0 & 30.0 & 23.3 \\
\hline 4 & Less Recommended & 3.3 & 0 & 10.0 \\
\hline 5 & Not Recommended & 0 & 3.3 & 3.3 \\
\hline & Total & $\mathbf{1 0 0 . 0}$ & $\mathbf{1 0 0 . 0}$ & $\mathbf{1 0 0 . 0}$ \\
\hline
\end{tabular}

\section{Hypothesis Testing}

The Mann-Whitney $U$ test is to test significance of difference between the medians of two samples. The null hypothesis is that the two samples are taken from the same population and there should not be a consistent difference between the two sets of values while the alternate hypothesis is set as that the companies have not favored the bill of guarantees offered in MSC policy and it has no significance. The population is then divided into two groups according to the time duration located in the MSC consisting of companies located there, longer than five years and companies located less than five years and then been tested on the hypothesis.

The sample has been distributed into the two groups according to the time of location in the area. This was to understand the difference in response of companies taking up the MSC status in the initial development phase and later on when it was well into development. This was expected to show some difference in the choice of incentives offered in the MSC policy as driver to shift office from existing location overtime. 
Table 6: Summary of Mann-Whitney U test

\begin{tabular}{|l|c|c|}
\hline \multicolumn{1}{|c|}{ Bill of Guarantees } & $\begin{array}{c}\text { Mann-Whitney U } \\
\text { @ Critical Value } \\
\mathbf{( 6 2 . 0 0 0 )}\end{array}$ & Asymp. Sig. (2-tailed) \\
\hline $\begin{array}{l}\text { World Class Physical } \\
\text { Infrastructure }\end{array}$ & 81.000 & 0.373 \\
\hline $\begin{array}{l}\text { Unrestricted Employment of } \\
\text { Foreign Workers }\end{array}$ & 80.000 & 0.360 \\
\hline Freedom of Ownership & 89.000 & 0.613 \\
\hline Global Sourcing of Funds & 63.500 & 0.094 \\
\hline Tax Exemption & 76.000 & 0.205 \\
\hline IPP and Cyberlaws & 89.500 & 0.630 \\
\hline No Censorship of Internet & 74.000 & 0.231 \\
\hline Competitive Telecomm Tariffs & 77.000 & 0.231 \\
\hline MSC Infrastructure Tenders & 86.500 & 0.537 \\
\hline One Stop MSC Super shop & 78.000 & 0.307 \\
\hline \multicolumn{2}{|l}{} \\
\hline
\end{tabular}

Testing of hypothesis has shown a significant difference in two variables of tax exemption and global sourcing of funds at 95 percent reliability level as been summarized in Table 6. As tax exemption was the top choice for taking up MSC status by the companies locating in the area before five years of time which has become less important overtime and it was envisaged that companies taking up the MSC status now, are valuing the allowance of global sourcing of funds and to borrow funds globally in addition to other incentives offered. Therefore, it is concluded as that the choice to relocate overtime is proportional to overall competition in global market for which a long term policy is not a recommendation but there is a need of change in policies at a certain interval of time according to the market politics.

Besides the Bill of Guarantees it has also been suggested by the respondents that the rental rates for property are higher in the MSC area. Although, being cheapest in the region they are equivalent to any prime location in the city of Kuala Lumpur and also that space available for rent is quite limited and there is not much choice. In addition, the lack of public amenities such as; public transport, residences, restaurants, public telephone booths, etc. is needed for people working in the MSC area.

\section{Conclusion}

It has been observed that there has been a difference in attraction of different factors in different time frames on choice of location to decentralize office activities in the case of MSC supporting the ever evaluating process of policy making. The infrastructure provided in the MSC is one of its kind in the region having 99.9 percent reliability (Nasscom, 2003), and thus making Malaysia the third most suitable place for business outsourcing (Kearney, 2009). Although the bill of guarantees offered in the MSC policy is quite comprehensive but overtime, same incentives have been offered in many other countries as it has become a need for developing companies to 
retain information incentive companies in order to remain competitive in the global arena. It has been found that there is a significant need to develop more office space on lower rental basis as well as development of cheap and convenient way of transport, provision of residence for workers in MSC and development of basic public amenities. It can be said that MSC progress has been up to the mark since its time of inception and that there is a great potential in this corridor to contribute towards Malaysian vision of converting its economy into knowledge based economy

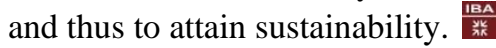

\section{References}

Abler, R. (1970) What makes cities important, Bell Telephone Magazine, 49, pp. 10-15.

Brandt, R. (1991) Can the U.S Stay Ahead in Software? Business Week, March 11, pp. 98-105.

Bunnell.T., Barter PA. and Morshidi. S. (2002) City Profile- Kuala Lumpur Metropolitan Area, A Globalizing City-Region, Cities, 19(5), pp. 357-370.

Carillo, F. (2006) Knowledge cities: approaches, experiences and perspectives, New York: Butterworth-Heinemann.

Castells, M. (1996) Relationships of Advanced Information Technology, Economic Organization, and the Social Structure of Cities, M.I.T. Colloquium on Advanced Information Technology, LowIncome Communities, and the City, March 1996, M.I.T, Boston, pp. 1-15.

Campos, Nauro F., and Yuko Kinoshita (2003) Why Does FDI Go Where it Goes? New Evidence from the Transition Economies, International Monetary Fund working paper no. WP/03/228.

Department of Statistics (1998) Business Expectation Survey of Limited Companies - First Half, Malaysia Kuala Lumpur.

Dickstein C. (1992) Back Office and West Virginia, West Virginia Public Affairs Report, No. 9, pp. 2:1-7.

Drucker, P.F. (1993) Post Capitalist Society, Harper Business, New York.

Goddard, JB. (1990) The Geography of the information economy, PICT Policy Research Papers No.11, Oxford.

Goff, L. (1990) U.S Programmer Shortage Spurs Offshore Software Development, MIS Week, January, pp. 20 - 28.

Gosling, P. (1997) Government in the Digital Age, London: Bowerdean Press.

Graham, S. and Marvin, S. (1996) Telecommunication and the City: Electronic Spaces, Urban Spaces, London: Routledge.

Guldman, J.M. (1994) Input-Output Modeling of Regional Telecommunication Flows, Columbus, $\mathrm{OH}$ : Ohio State University, Center for Advanced Study in Telecommunications.

Henton, D. and Walesh, K. (1998) Linking the new economy to the livable community, April. Report to the James Irvine Foundation, San Francisco.

Johnston, W.B. (1985) The Coming Glut of Phone Lines, Fortune, January. 
Jebson, A. (2003) Outsourcing to India: the next steps - The Future of Work Migration: an International Bank’s Perspective Financial Times Conference, Speech by Group Chief Operating Officer, HSBC Holdings plc, November.

Katz, B. (2002) Smart growth: The future of the American metropolis? CASE paper 58, London: Centre for Analysis of Social Exclusion, London School of Economics.

Kearney, A.T. (2009) The Shifting Geography of Off shoring - The 2009 A.T. Kearney Global Services Location Index ${ }^{T M}$, http://www.atkearney.com/, A.T. Kearney, Inc.

Kutay, A. (1989) Effects Of Telecommunications Technologies on Office Location, Urban Geography, 7(3), pp. 243-257.

Landry, C. (2008) The Creative City: A toolkit for urban innovators, $2^{\text {nd }}$ Edition, Comedia, London.

Landry, C. (2000) The Creative City, London: Earth Scan.

Ludlum, D. (1987) Irish Woo Software Operations, Computer World, March 2, pp. 57-65.

Lund, J. and Mukhtarian, P. (1994) Telecommuting and Residential Location: Theory and Implications for VMT in Monocentric Metropolis, Transportation Research Record.

Malaysia (2001) Eighth Malaysia Plan 2001 - 2005, Economic Planning Unit, Prime Minister’s Department, Malaysia.

Malaysia (2003) Draft Structure Plan Kuala Lumpur 2020, City Hall Kuala Lumpur, pp. 8-10.

Malaysia (2001) Developing Malaysia into a Knowledge-Based Economy, Third Outline Perspective Plan 2001-2010, City Hall Kuala Lumpur; (OPP3), pp. 1-10.

Malaysia (2004) Structure Plan Kuala Lumpur 2020, City Hall Kuala Lumpur, pp. 2-3, 4-1, 4-2.

Mandeville, T. (1983) The Spatial Effects of Information Technology, Futures, 15(1), pp. 67- 69.

Mitchell, W. (1995) City of Bits: Space, Place and the Infobahn, Cambridge, Ma: MIT Press.

Mokhtarian, P, Handy, S. and Solomon, G. (1994) Methodological Issues in the Estimation of Transportation, Energy and Air Quality, Impacts of Telecommuting, Transport -Research.

Moss, W. (1999) Personal communication with Bits, Coldwell Banker.

Mulgan, P. (1991) The Changing Shape of the City, In Stuart Hall and Martin Jacques (eds), New Times, London: Lawrence and Wish Art.

Multimedia Development Corporation (2003) IT Shared Service and Contact Centres - Establish A World Class Hub in the MSC, Cyberjaya (Selangor, Malaysia): Trade Booklet.

Multimedia Development Corporation (2004) Multimedia Super Corridor - Impact Survey 2004 Report, Performance of MSC-Status Companies in Phase I, Cyberjaya (Selangor, Malaysia): Trade Booklet and Brochure.

Multimedia Development Corporation (2004) Flagship Applications- A Gateway to the Future, Cyberjaya (Selangor, Malaysia): Trade Brochure. 
Multimedia Development Corporation (2008) Multimedia Super Corridor - Cyberjaya Updates, First Quarter 2008 Report, MSC Malaysia Cyber cities department (Selangor, Malaysia): Trade Booklet and Brochure.

NASSCOM (National Association of Software and Service Company) (2003) Relocating the Back Office - Off-shoring- The benefits of off-shoring, The Economist, Saturday, December 13.

Netzer, D. (1985) State Tax Policy and Economic Development: What Should Governors Do When Economists Tell Them That Nothing Works? Working Paper, New York University Urban Research Center.

Nilles, J. M. (1991)Telecommuting and Urban Sprawl: Mitigator or Inciter? Transportation Journal, pp. 1-15.

Prud'homme, R. (1992) Cities and New Technologies, New Technologies and Local Economic Development, In: Organization for Economic Co-operation and Development, Paris, pp. 269-283.

Sassen, S. (2000) Cities in a World Economy, $2^{\text {nd }}$ Edition, Pine Forge Press, Thousand Oaks, California.

Stirland, S. (1997) Wall Street and Technology, ActiveX vs. Java.

Stutz, F.P., and de Souza, A.R. (1998) The World Economy; Resources, Location, Trade, and Development, 3rd Edition, Prentice-Hall, Upper Saddle River, New Jersey.

Tagare, S. (1989) Better Communications Let Firm Farm Out Work, Network World, November,7(21), pp. 60-62.

Wong. T.C. (2003) The Changing of the Central Business District In The Digital Era: The Future of Singapore's New Financial District, Land Use Policy, National Institute of Education, Nanyang Technological University. 